\title{
The Selection of News in the International Reporting of the Macedonian, Slovenian and Serbian Daily Newspapers (2013-1989-1983)
}

\section{Bojan Blazhevski, Macedonia}

\begin{abstract}
This paper aims to present the selection of news in the international reporting of the daily newspapers from Macedonia, Slovenia and Serbia in a distance of three decades. We begin this study by using the method of quantitative content analysis. Results give concrete number of articles, photographs and other content published in foreign policy sections of the newspapers Nova Makedonija, Vecer, Delo and Politika. The data analyzed was gathered over a four month period, from the years 2013, 1989 and 1983. Analysis demonstrates significant drop of the number of media content for international events printed in 2013, a period during which are also allocated fewer pages to foreign policy sections. With the exception of the Serbian newspaper Politika, international events in the printed editions are usually published after those media content dedicated to internal political issues and economic topics from Macedonia and Slovenia. This empirical research proves that international reporting in the Macedonian, Slovenian and Serbian newspapers is experiencing a serious decline today without any prospect of improving the current situation in the next period.
\end{abstract}

Keywords: Gatekeeping, international reporting, daily newspapers, the Republic of Macedonia, the Republic of Slovenia, the Republic of Serbia, the SFR Yugoslavia. 


\section{Introduction}

Walter Lippmann in his epoch book "Public Opinion” writes:

“...every newspaper when it reaches the reader is the result of a whole series of selections as to what items shall be printed, in what position they shall be printed, how much space each shall occupy, what emphasis each should have. There are no objective standards here. There are conventions". (Lippmann, 1954: 354 in McNair, 2011: 25).

A few decades later, modern digital journalism has changed very little, at least in the segment of the selection of news. Grounded on their media agenda, journalists decide what is worth for publishing over against those international events excluded from the pages of the foreign policy sections. Today, we have much more media content and channels for their transmission, but fewer journalists inside them. According to Robert W. McChesney, international coverage today is a victim of corporate cost cuts. "It costs far more to do hard investigations than it does to do official source stenography, and requires skills experienced journalists" (McChesney, 2008: 43). Nick Davies argues that we have journalists who do not produce original content. Instead of that, there is domination of agency news, official sources and spinning articles in media outlets (Davies, 2009). According to Hachten and Scotton, journalists are less serious in their work, while the Internet is 'flooded' with unconfirmed, inaccurate, biased, propagandistic and misleading information (Hachten, Scotton, 2012). But, even in this unfavorable situation, international reporting is based on the daily selection of news. The choice of topics, the number of articles and pages in newspapers and their positioning is a matter related to gatekeeping.

Neither in theory, nor in practice, is possible to publish report on every single international event that happened in a country at the other end of the Earth. At this point, the selection of news begins to operate. "Studies of newsroom decision-making illustrate journalist's response to a collegial climate resting on the real or assumed interests (or actual interventions) of publishers, stockholders, advertisers, parties, public organizations, or government that set the terms of employment" (Gerbner \& Marvanyi, 1975: 4). In a pluralist media system, such as the American, media do not function in the manner of propaganda system of a totalitarian state. "Rather, they permit-indeed, encourage-spirited debate, criticism, and dissent, as long as these remain faithfully within the system of presuppositions 
and principles that constitute an elite consensus, a system so powerful as to be internalized largely without awareness" (Chomsky \& Herman, 1988: 302).

The selection of news is one of the tools in hands of media workers that can form the international reporting. Modern 'gatekeepers' have to perform in the age of Internet, a time when is much harder to hide certain information from the public. On the other hand, we should take in consideration that news events are closely connected with news values and editor's judgments. With empirical results on board, Tai Zixue explains the difference between published media material of the Japanese Kyodo News Service, the Chinese Xinhua News Service and the Taiwanese Central News Agency.

"All three news agencies showed a difference between their evaluations of domestic and world events. Hot international topics for all three agencies were diplomacy, war/conflicts, financial and economic affairs. Their rankings of domestic events, however, differed considerably from each other, although internal politics topped the domestic event lists of all three" (Zixue, 2005).

Michael Kunczik and Astrid Zipfel in their book "Introduction to the Science of Publicism and Communication" give a rational definition of the gate-keeping theory. According to them, gatekeeping means same as limiting the amount of information, or more precisely, selection of topics that are considered suitable in mass-media. "Gatekeepers decide which events will become public, and thus contribute to the formation of recipient's vision about the society, or the world" (Kunczik \& Zipfel, 1998: 123).

One clear example of this definition is given in the Elizabeth Bird's book "The Antropology of News \& Journalism: Global Perspectives". In her book she describes the selection of photographs about the construction of concrete wall between Israel and the West Bank in Palestine. She is a witness of the editorial preparation of the next issue of an American political magazine. Together with her, in the newsroom are three editors, named like Jen, Sarah and Mary (art director, text editor and editor of photography). The selection of received photographs for this event from the Middle East goes like this:

"Mary: I like the feel of that one. That one is good for compositional difference.

Sarah: The dustiness of the background, everyday life... Which of these photos do you like? (She shows two separate photos of women crossing the wall). Here is a 
traditional woman, a working woman so the empathy factor is higher. (She then looks at an image showing an unveiled pretty young blonde in jeans). I'd be very shocked if that was a Palestinian woman.

Jen: Why?

Sarah: She looks so modern.

Jen: According to the caption, she's Palestinian. But I'll check.

Sarah: (reaching for an another image) Here you see old women and children, so obviously there are not the elements to cause trouble in the world. So you get the sense that this wall is just a total inconvenience. Then I like this one because you have every type of person in it.

Jen: You can see how they are living in this desolate landscape. To me the checkpoint is a more familiar image, so it's not surprising.

Mary: That one's a bit graphically difficult for me because it's a different shape, but I can practically hear what's going on" (Bird, 2010: 43).

This example explains how the process of news selection works in the international reporting. However, there are certain values introduced in the daily work of journalists. Thomas Meyer in his book "Media Democracy: How the Media Colonize Politics" claims that journalists with this process put attention on transience of the event, its spatial, political and cultural closeness, the value of surprise in those information within the already known topics, the level of conflict in the event and the major damage or special successes and achievements (Meyer, 2003: 24). John Street is trying to give a definition of what constitutes the value of the news, in short and simple way. "Value is a working assumption of the journalist in the matter of how much some event is important and why it is important" (Street, 2003: 18). All of this should be taken into account when analyzing the selection of news in the media.

\section{Methodology}

Starting from this theoretical basis for the selection of news, this paper focuses on the research of the selection of news for international events in the newspapers from the former Yugoslavia. This paper tries to present small part of the doctoral dissertation that gives empirical results about the dependence of global media in the international reporting of the daily newspapers from Macedonia, Slovenia and Serbia in three different periods - 1983, 1989 and 2013. Until the dissolution of the federation in 1991, Yugoslavia was one of the 
most important members of the Non-Aligned Movement. According to the book "International Relations and Foreign Policy of Yugoslavia", there were two decisive reasons for choosing the non-aligned policy in Yugoslavia from the mid-1950's until its breakup in 1991. The danger of military invasion by the Soviet Union and insufficient confidence in the Western bloc countries were crucial for Yugoslavia to participate in the formation of the Non-Aligned Movement in Belgrade in 1961 (Gavranov \& Stojkovic, 1972). Edvard Kardelj in his book "The Historical Roots of Non-Alignment" mentions the importance of Yugoslavia in the historical development of the Non-Aligned Movement (Kardelj, 1985). As a result of this, Yugoslavia had a very powerful national news agency called Tanjug. In 1975, it took the initiative for creation of the Non-Aligned News Agencies Pool (NANAP) (Shafer, 1997). Tanjug decided to be founder of this network after the Fourth Non-Aligned Summit held in Algeria in 1973 (Topuz, 1977). The active role of Yugoslavia on the international political scene was accompanied by an in-depth reporting on international events of the Yugoslav news agency Tanjug. However, the Yugoslav media system was decentralized. "Each of the republics - members of the Federation had its own communication system, which was largely independent of the central government" (Radeljic, 2012: 123). The complex Yugoslav situation was inspiration for this article. On one side, this paper tries to describe the regional differences in the selection of news for international events among Yugoslav newspapers during the 1980's. On the other side, this research aims to show the historical development of the international reporting from a distance of three decades. Today, the news agency Tanjug almost disappeared from the international media scene as a result of the breakup of Yugoslavia. After two and a half decades, the Republic of Slovenia today is a NATO member, Macedonia has clear aspirations for Euro-Atlantic integration, while Serbia wants to keep its military neutral status, but it has a clear goal of joining the European Union (Novakovic, 2012; Fenko \& Sabic, 2013; Nacev \& Petreski, 2013).

Using the method of quantitative content analysis, this paper reveals the number of published articles, photographs and other types of content (tables, maps, cartoons, graphs, etc.) for international events in foreign policy sections of the Macedonian, Slovenian and Serbian newspapers. Also, on the basis of observation of the printed editions of these daily newspapers, this paper presents empirical results for the number of pages allocated to foreign policy sections and their position in the printed editions. This research includes those newspapers that have been printed for three decades continuously. With the usage of simple 
random sampling, in the research process were included newspapers Nova Makedonija and Vecer from the Republic of Macedonia, Delo from the Republic of Slovenia and Politika from the Republic of Serbia. The research period covers randomly chosen time dynamics, which includes the following dates: from 1 to 7 September, from 8 to 14 October, from 15 to 21 November, and from 22 to 28 December 2013, 1989 and 1983. It is a research period that includes the newspaper editions published on same days, within three different years. As a result of this methodological framework, empirical results were obtained for the selection of news in the international reporting of Macedonian, Slovenian and Serbian newspapers in 2013, 1989 and 1983.

\section{The selection of news in the international reporting of Macedonian daily newspapers Nova Makedonija and Vecer (2013-1989-1983)}

In the research period of 2013, in foreign policy section of the Macedonian daily newspaper Nova Makedonija were published 105 articles, 98 photographs and 26 other types of content (charts, graphs, maps, caricatures and etc.) for international events. Articles were also published in the supplement of this newspaper, which is called "Selection of the world press". Smaller amount of texts were printed in the section dedicated for commentaries and debates. Empirical results show the current growth of the visual material, which occupies equal space with the written content in those editions published in 2013. According to the results, the number of textual material for foreign policy events is drastically reduced. The selection of news in the 2013 printed editions is oriented toward information and analysis for internal political developments in Macedonia, with a significant increase in pages intended for sport news, entertainment and advertising.

In the identical time period of 1989, in foreign policy section of the newspaper Nova Makedonija were published 514 texts, 93 photographs and 18 other types of content for events that took place in other countries. Similar results were obtained for the period from September to December 1983, when in foreign policy section were published 470 articles, 47 photographs and 10 other types of content for novelties from abroad. As we can see, there is domination of textual material over photographs in the international reporting. Also, one should note that this is a historical period in which Yugoslavia based its international activities on the politics of non-alignment. 
Graph 1. Number of published media content for international events in the Macedonian newspaper Nova Makedonija

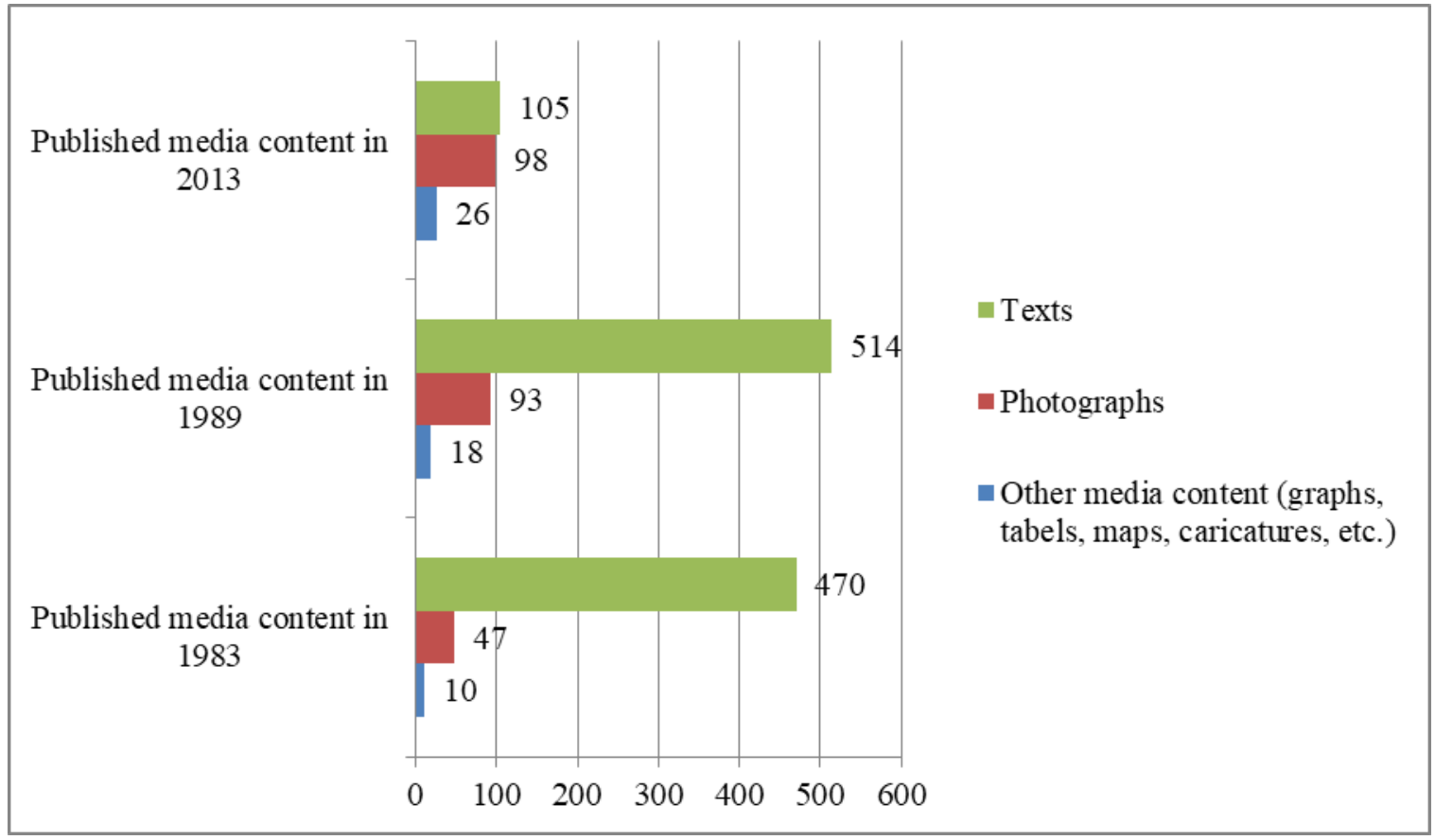

The current situation of 2013 suggests that international events in the newspaper Nova Makedonija are covered on one or two pages in a single printed issue, while editions published during the 80-ies of XX century had almost twice bigger space for actualities from abroad. During this period, editors of the newspaper Nova Makedonija placed media materials for actualities from abroad on two to five pages. All important events from abroad were regularly published on the front page of this newspaper. On the other hand, the total number of pages of the daily newspaper Nova Makedonija in all three periods of research was not drastically changed. Average daily printed editions had from 24 to 32 pages.

Another indicator for further reduction of the editorial interest in international events is the fact that foreign policy section in the 2013 printed editions was moved after sections "Macedonia" and "Economy", so it was regularly published on pages 8, 9 or 10 of the newspaper. Foreign policy section in the editions of 1983 and 1989 is mostly placed on the first five pages in printed editions of the newspaper Nova Makedonija. Besides the established selection of news by the editorial staff, these empirical results confirm that international news were put on priority level in the grounded media agenda of Nova Makedonija. 
The situation is identical with the Macedonian newspaper Vecer. There are constant cuts of media content for international events in the last three decades. In the 2013 printed editions were published 294 texts and 207 photographs for events from abroad placed in foreign policy sections "Balkan" and "World". Current editors of the newspaper Vecer overwhelmingly used photographs to visually present international events. At the same time, one should not ignore the fact that the newspaper Vecer is a tabloid, according to its format and content. "Yellow press" usually uses a lot of photographs to gain the attention from their readers, but also editorial offices pay less attention to international events in comparison with other segments of the newspaper, such as entertainment, sport, or crime. The Macedonian daily newspaper Vecer changed its format and content in the past three decades. During the 80-ies of XX century, the newspaper Vecer intended to give appropriate content to all members of the family, as a depoliticized print media that deals with the growing life problems of the ordinary reader, oriented especially to those people that live in the Macedonian capital. This drastic shift of the editorial line also had a significant effect on the media content for international events.

Graph 2. Number of published media content for international events in the Macedonian newspaper Vecer

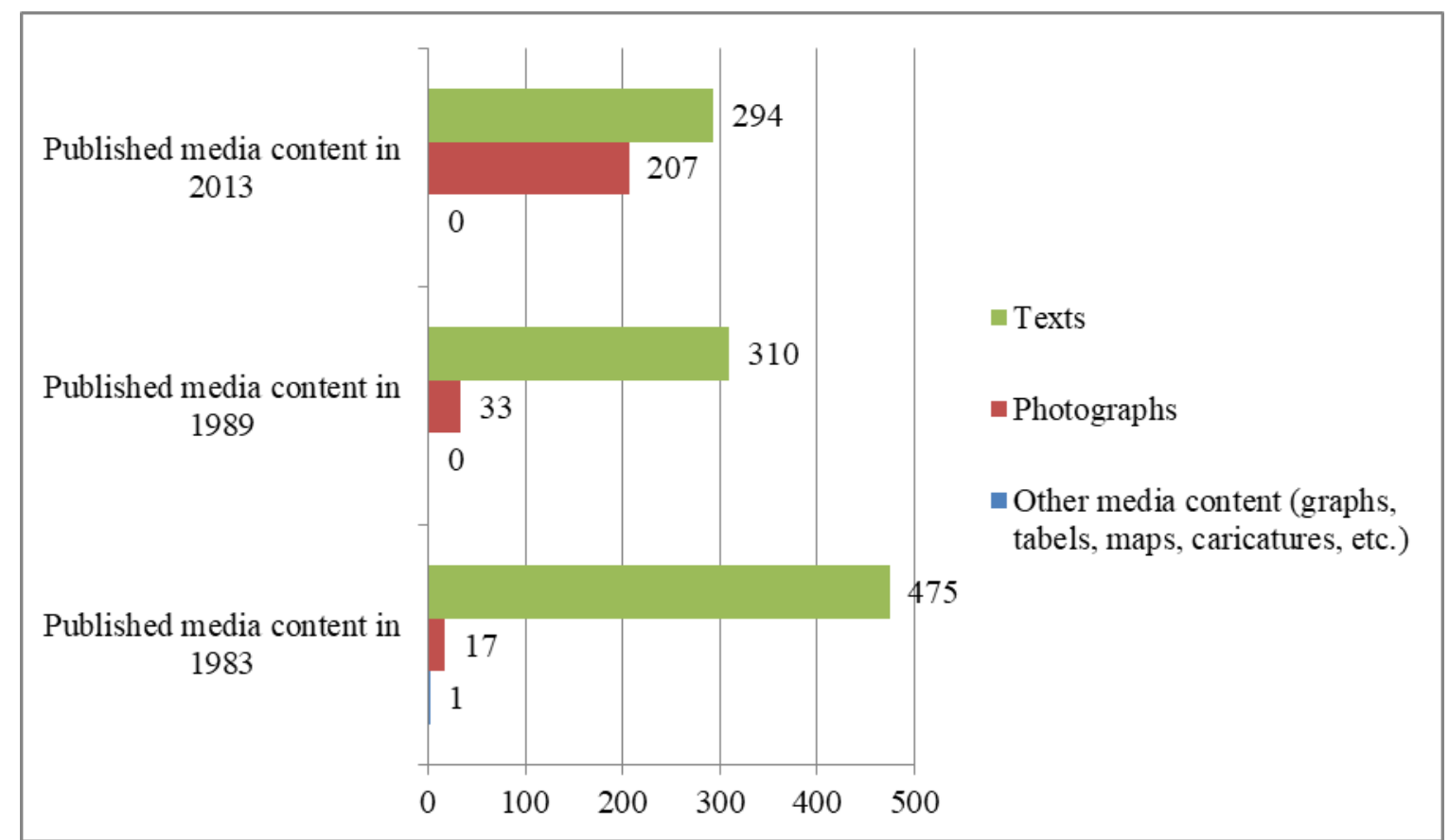


The quantum of published media content continuously decreases over the years from 1983 to 2013. In the 1989 printed editions were placed 310 articles and 33 photographs for international events. Larger number of textual and visual material is published in the 1983 printed editions. During this period, in the newspaper Vecer were printed 475 texts and 17 photographs related to actualities from abroad. In terms of the number of pages allocated to foreign policy events in 2013, editors of the newspaper Vecer today give an average of two to three pages for international events in one printed issue. This media content is placed after those articles that treat internal political issues, crime stories, economy and local news from the Macedonian capital. Research results show that international news were published on pages $14,15,16$ or 17 of the total 32 pages in one printed issue of the newspaper Vecer.

Media materials for international topics in the 1983 and 1989 printed editions were usually placed on two to four pages in one issue of the newspaper Vecer. It is slightly bigger space than the 2013 printed editions, if we take in consideration the fact that the newspaper Vecer during the 80 -ies of XX century had a total of 32 pages in one printed edition. In that period of time, the editorial staff of this newspaper gave priority to foreign policy events, moving them on the first six pages of one printed issue. All empirical results describe the greater importance given to international reporting by the editors and journalists of the newspaper Vecer during the 80-ies of XX century as opposed to 2013.

\section{The selection of news in the international reporting of Slovenian daily newspaper Delo (2013-1989-1983)}

In the 2013 printed issues of the Slovenian newspaper Delo were published 266 articles, 180 photographs and 7 units of other media content (charts, graphs, maps, caricatures, etc.) for international events. In this analysis were included all articles placed in the weekend supplement "Sobotna priloga", but also analytical texts for international events included in the section "Mnenja". Obtained results show significant reduction of the media materials that treat actualities from abroad.

The editorial selection of news in the newspaper Delo is oriented toward those events taking place within the country, a process that receives constant growth from 1983 to the present day. International affairs over the period have smaller priority in the established media agenda. Empirical results clearly present that in the 1989 printed editions were published 637 
texts, 92 photographs and 33 other types of content (charts, graphs, maps, cartoons, etc.) for events from abroad. The situation with international reporting is worse in comparison with printed issues of the newspaper Delo in the early 80-ies of XX century. In the period from September to December 1983, foreign policy section contains 949 articles, 24 photographs and 7 units of other content for actualities out of the SFR Yugoslavia.

Graph 3. Number of published media content for international events in the Slovenian newspaper Delo

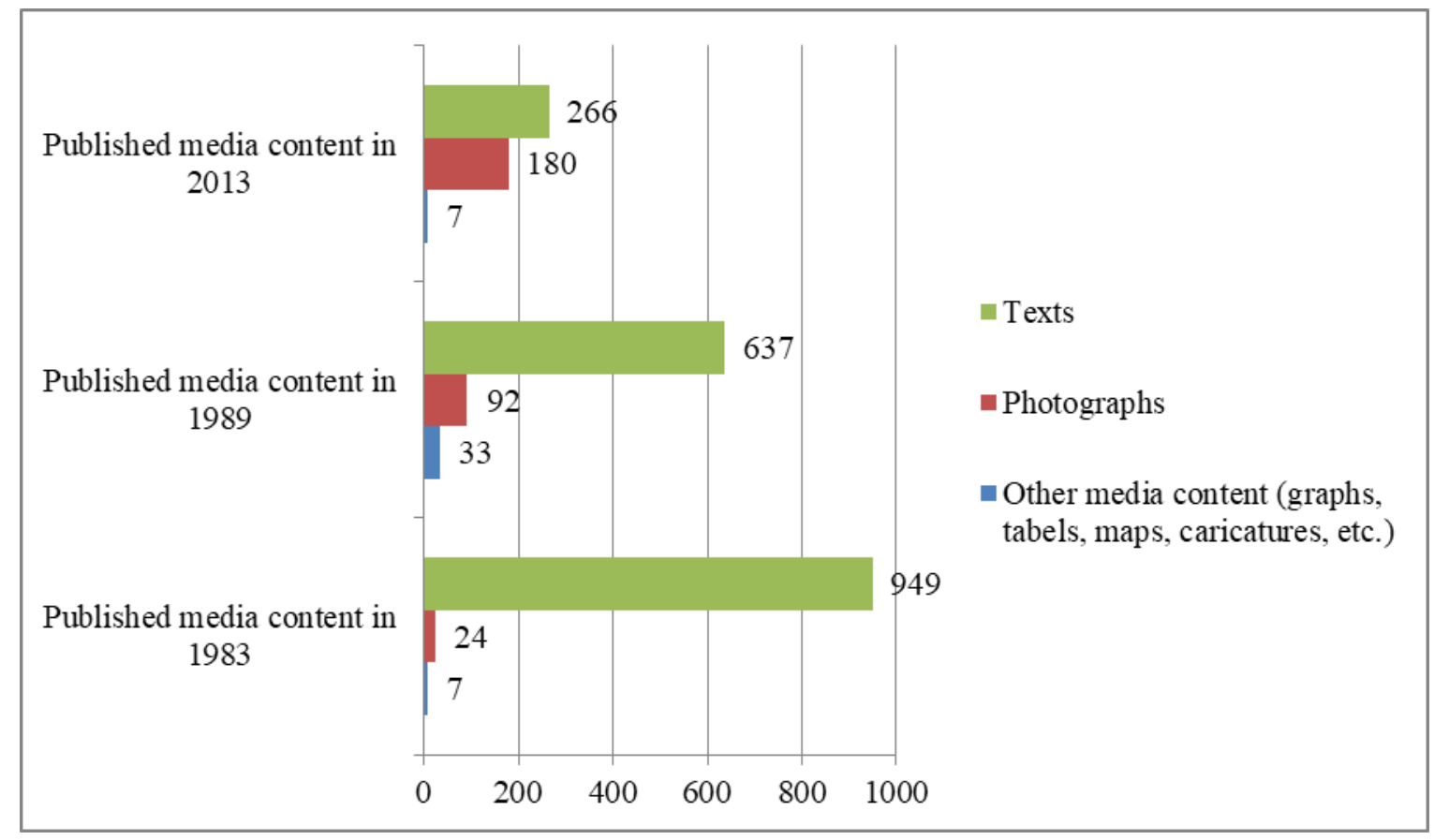

Journalistic articles are key content for international events in foreign policy section of the newspaper Delo. An exception to this are the 2013 printed editions with their significant space given to photographic content that visualize international actualities. Another indicator that shows declining interest for foreign policy reporting by the editorial staff is the number of pages allocated for media coverage of events. Two or three pages of the 2013 printed editions are dedicated to those events that occurred outside of Slovenia. International reporting is usually located on pages 5, 6 or 7 in one printed issue of the newspaper Delo, which contains total number of 24 or 32 pages. All media content is placed after those sections dedicated to analysis and commentaries about actual themes. 
Contrary to the 2013 printed editions, the Slovenian newspaper Delo in 1983 and 1989 gave larger space for reporting on international actualities. Foreign policy sections were usually placed on two or three pages devoted to those events that occurred outside of Yugoslavia. Journalistic reports from abroad were most commonly positioned on pages $1,4,5$ or 8 , and also, on the last page of this newspaper. In the period from September to December 1989, one issue of the newspaper Delo had a total number of pages in range of 16 to 32. The empirical results clearly show that the editorial staff of this newspaper gave higher priority to international news in the 1983 and 1989 printed editions. These data follow the conclusion that reporting for events from abroad at that time was established as the highest priority in the media agenda.

\section{The selection of news in the international reporting of the Serbian daily newspaper Politika (2013-1989-1983)}

During the research period of 2013, the Serbian daily newspaper Politika published 599 texts, 235 photographs and 22 units of other media content (tables, graphs, maps, caricatures, etc.) for international events. All media material was placed in foreign policy section, but also on those pages dedicated for publishing columns, commentaries and analysis. Empirical results can clearly describe that the editorial staff is oriented toward greater media visualization of all international events treated in the newspaper. Besides the continuous growth of photographic material, international reporting of the newspaper Politika in 1983, 1989 and 2013 was mainly grounded on articles that elaborate topics for actualities from abroad. Even in 2013, the editorial staff shows that their priority in everyday work was put on textual content for international events. These results indicate constant high quality of international reporting in the whole period from 1983 to 2013.

This analysis for the 2013 printed editions suggests that foreign policy events are placed on three to five pages in one printed issue of this newspaper. Three decades ago, editors of the same newspaper allocated usually from four to five pages for international events. Therefore, one can conclude that the average media space for international events is minimally reduced in those issues printed in 2013. This is another indicator that can confirm that the editorial staff of the newspaper Politika gives continuous attention on actualities that happened outside of Serbia. We have to stress that the leading Serbian newspaper in all three periods keeps its international reporting as a high priority in the established media agenda. World events in the 
printed editions of 2013, 1989 and 1983 are ranked as the most important media content. Besides on the front page, foreign policy reporting was placed on pages 2, 3 and 4 of this newspaper. In some cases, even larger space was allocated. These empirical results may confirm the continuing effort of the editorial board to maintain their prestige as the most prominent and influential daily newspaper in the Republic of Serbia for more than three decades.

Graph 4. Number of published media content for international events in the Serbian newspaper Politika

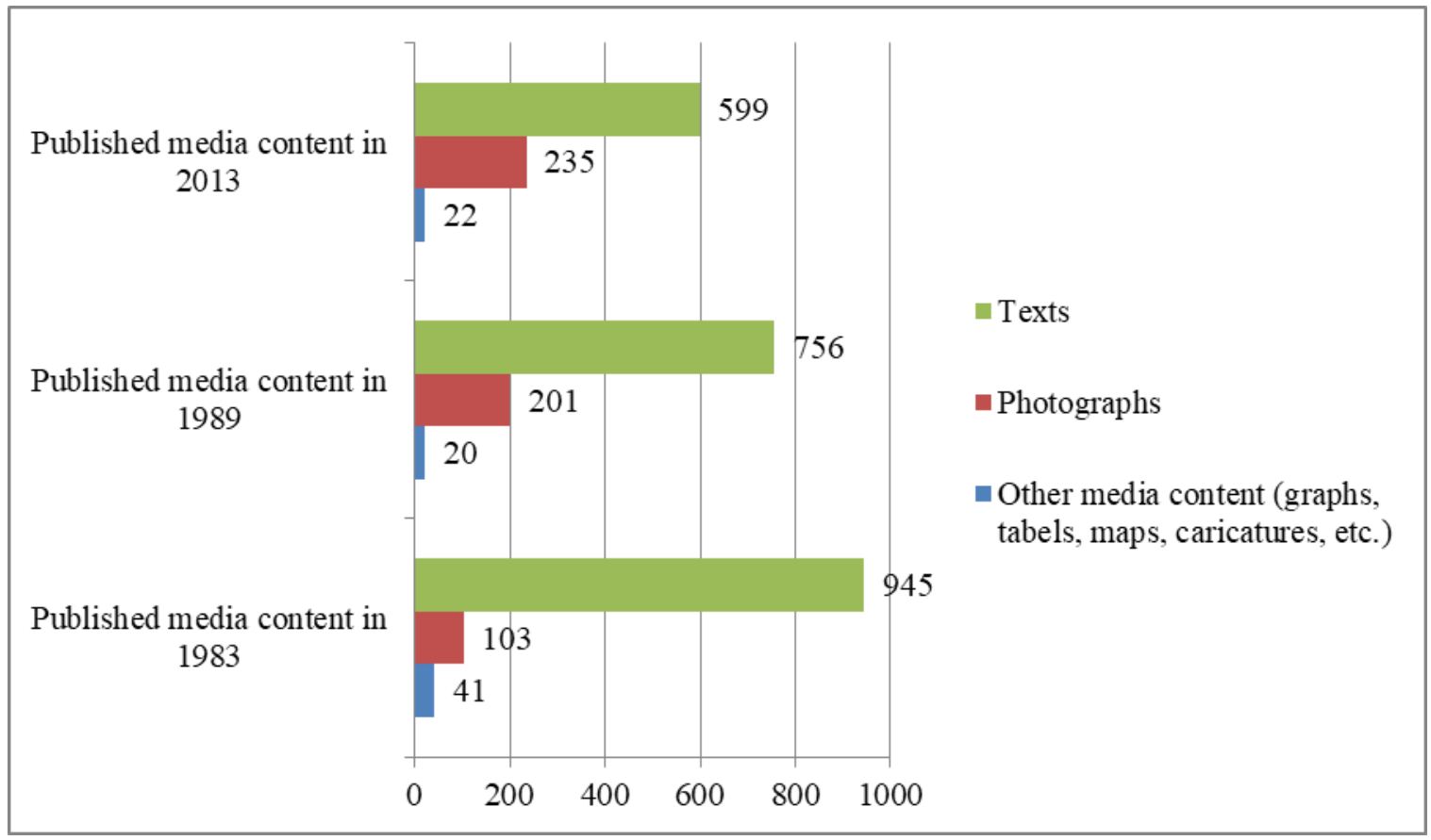

Contrary to this positive tendency of journalistic work, quantitative content analysis has emphasized the negative trend of reducing the textual content in the printed issues of the newspaper Politika. Today, there are almost twice less articles for actualities from abroad, compared to those issues printed in the identical period of time in 1983. The Serbian newspaper Politika in 1989 published 756 articles, 201 photographs and 20 units of other media content (charts, graphs, maps, caricatures, etc.) for international events. Actualities that happened outside of SFR Yugoslavia were treated on the front pages of the newspaper. In the 1989 editions were allocated three to four pages for international events. The editorial staff of the newspaper Politika gave priority to foreign policy events, giving them large space on the front page, but also on pages 2, 3 and 4 of the printed issues. 
Quantitative content analysis of the 1983 printed editions shows that most of the media content was dedicated to reporting on international affairs. In the newspaper Politika were published 945 articles, 103 photographs and 41 units of other content (tables, graphs, maps, caricatures, etc.). Comparing the quantitative empirical data, we can form conclusion that the greatest attention to international news was given in 1983. In this research period were published shorter texts, which directly affect on their overall number. However, another indicator can be included in the empirical results that support this thesis. In 1983, there were three to four pages allocated for actualities from abroad in one printed issue of the newspaper Politika. At the same time, international events were usually covered on the front page of this newspaper, but also on pages 2, 3 and 4 of one printed issue. These results are identical to the already formed conclusion on the international reporting of the Serbian newspaper Politika in 1989.

\section{Discussion}

There are obvious regional differences in the international reporting of the daily newspapers from the former Yugoslavia. Also, international reporting has its own characteristics in each of the three periods. Empirical results confirm that there are regional differences even in that time when Macedonia, Slovenia and Serbia were part of the SFR Yugoslavia. The regional comparison of the 2013 printed editions provides the most drastic contrasts to several issues.

The first difference from a regional perspective is the interest of the editorial offices for international events. Based on the quantum of published media content, it can be concluded that the editorial agenda of the newspaper Nova Makedonija is least oriented toward reporting on these topics in 2013. The number of published articles, photographs and other content is drastically higher in the newspaper Politika. The editorial staff of the Serbian newspaper has published five times more articles and almost three times more photographs than the Macedonian newspaper Nova Makedonija in the identical period of time. The Slovenian newspaper Delo in 2013 has published twice more textual material for international events than the newspaper Nova Makedonija. All these newspapers had the same format of publication. At the same time, they had significant impact on national public opinion with their serious treatment of international events. 
Graph 5. Number of published media content for international events in printed editions of Macedonian, Slovenian and Serbian newspapers in 2013

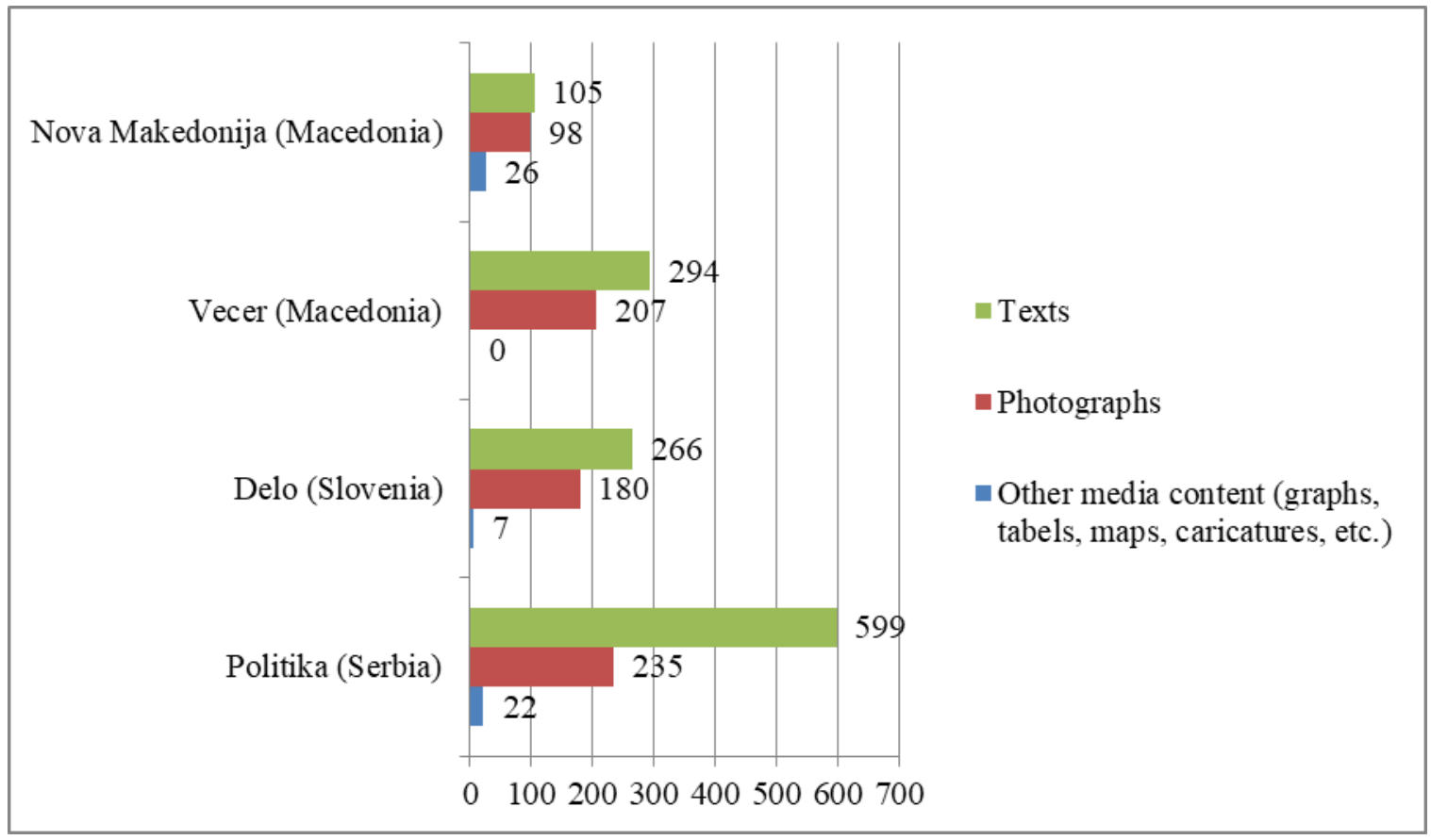

Following these quantitative results related to the international reporting, it can be concluded that the Serbian newspaper Politika gave the highest attention for those events from abroad. Its editorial agenda set these events in the first place. Based on this decision, editors and journalists select the media content on daily basis. After all, Michael Kunczik and Astrid Zipfel claims that "gatekeepers" in newsrooms decide which events will become public, adding that they even select the topics for publication in their media. In this case, the selection of news for international events is connected with the core agenda of the newspaper. 
Graph 6. Number of published media content for international events in printed editions of Macedonian, Slovenian and Serbian newspapers in 1989

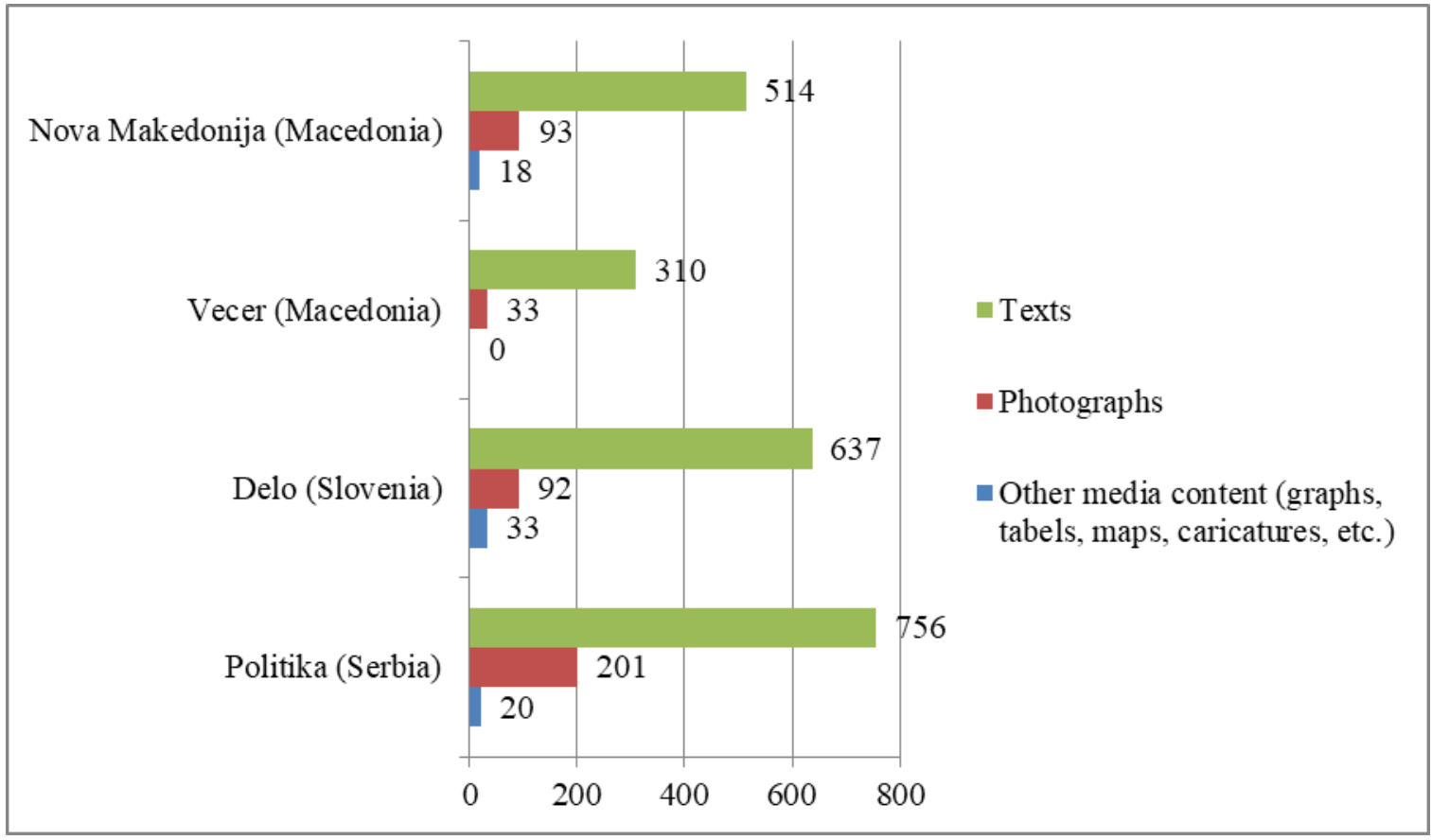

The reduced interest for international events between journalists from the newspaper Nova Makedonija is not present only in the printed editions of 2013. Within the Yugoslav media system, Macedonian print media have shown the lowest interest in events that happened outside of the SFR Yugoslavia. This was the case of the 1989 research period. One of the most important historical events from the last century happened in this period, such as the fall of the Berlin Wall, the collapse of the communist regimes in Eastern Europe, and the end of the Cold war. At the same time, there were many political conflicts among the republics and provinces in the former Yugoslavia.

The greatest attention for international events in the period September - December 1989 was shown by the newspapers Politika and Delo. In foreign policy sections of these daily newspapers were published between $20 \%$ and $50 \%$ more articles for foreign policy actualities compared to the Macedonian newspaper Nova Makedonija. The newspaper Vecer had a twice lower number of texts than the leading Slovenian and Serbian newspapers. Consequently, the quantitative research showed that international events had more relevance for the editorial staff of Politika and Delo than for those journalists and editors who created the printed issues of the Macedonian daily newspapers. The same approach of treating events was present in the 
1983 printed editions. Empirical results indicate that international reporting was drastically more developed in the Slovenian and Serbian print media. Openness to media coverage of foreign policy events was evident in the newspapers Politika and Delo. In those two media was published twice more textual content for international events compared with the Macedonian daily newspapers.

Despite these differences evident from regional perspective, international reporting received different attention among the same media in each of the three periods. The newspaper Vecer in the 2013 research period published two times more content for international events than in the 1983 printed editions. Enormous difference in the treatment of foreign policy affairs is also present in the other newspapers included in the research sample. The newspaper Nova Makedonija published four to five times less articles in the 2013 printed editions than in those issues published in the 80 -ies of XX century. This drastic situation can partly be explained by the fact that the newspaper Nova Makedonija in 2013 was primarily oriented toward publication of longer, analytical texts that needs significant space. On the other hand, the newspaper Vecer is a tabloid and publishes only short news about international events. From there comes the large number of published articles.

Graph 7. Number of published media content for international events in printed editions of Macedonian, Slovenian and Serbian newspapers in 1983

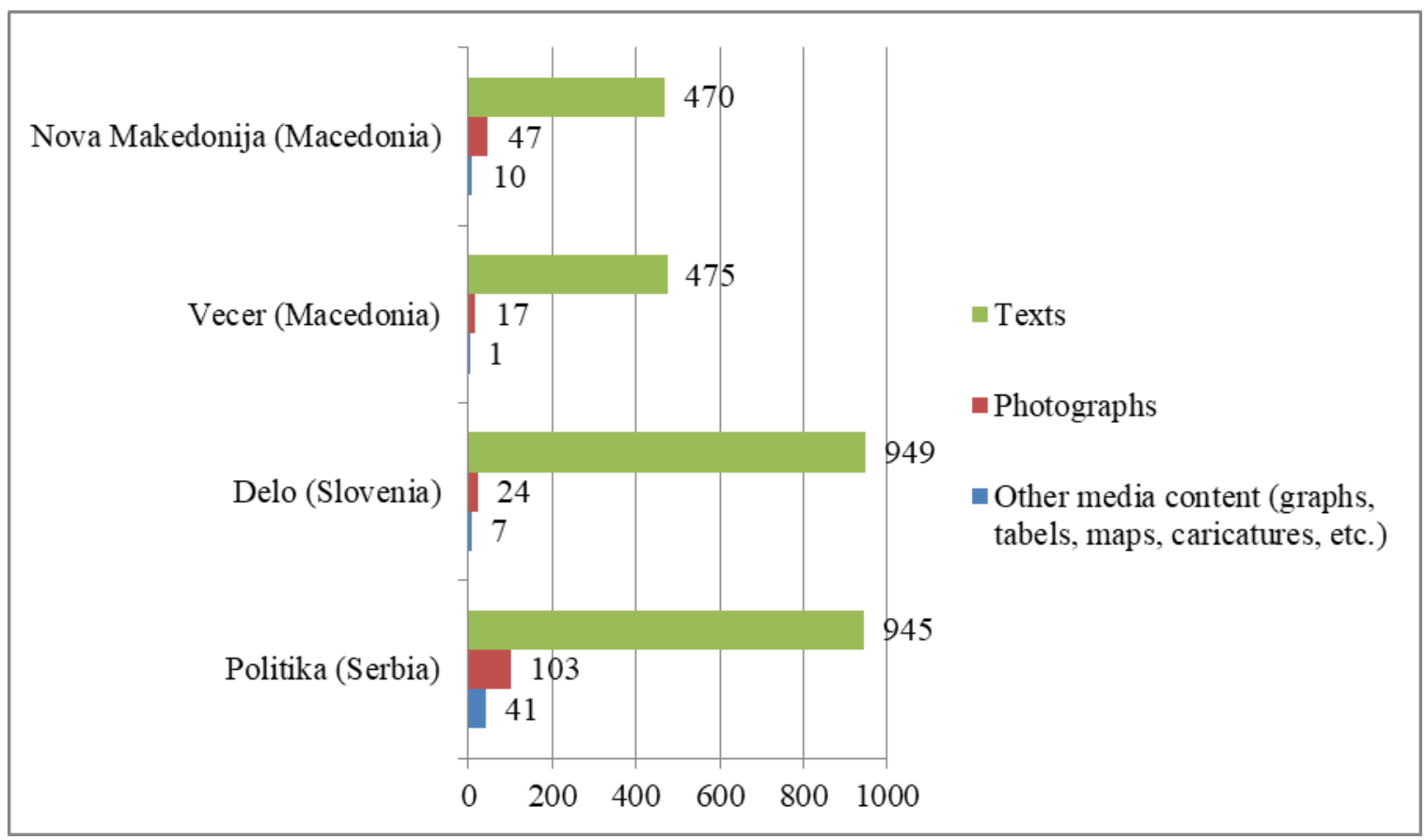


The editorial office of the Slovenian newspaper Delo in 1983 and 1989 has published two to three times more textual content compared to the 2013 printed editions. Two times less articles for international events are also produced today in the Serbian newspaper Politika, if we compare the number of journalistic texts printed in 2013 and 1983. To sum up, the identical decline is evident in the international reporting of all daily newspapers today, which shows that the general interest for events from abroad is lower among current editors and journalists of these media.

There are multiple reasons for these empirical results. First of all, Nick Davies argues that there are two reasons for poor international reporting in the media: the reduction in the number of journalists and the violation of professional journalistic standards (Davies, 2009). Unfortunately, all newspapers from the former Yugoslavia are not exception in this case. Their editor offices are following the global trend of the major western media. According to the author Lance Bennett, the public today receives less investigative journalism and more positive news about politicians and managers (Bennett, 2012). In addition to these global trends in journalism, in the case of former Yugoslavia there are several other reasons for the reduced interest in the international reporting. All three countries from the former Yugoslavia have different foreign policy priorities today in comparison with the former Yugoslav foreign policy. The role of these countries on the international political scene is minor. On the other hand, there is no regional media in the former Yugoslavia that has a more significant role in the global media system. Therefore, the national newspapers from Macedonia, Slovenia and Serbia are simply following the current level of development of their countries.

\section{Conclusion}

The international reporting of the Macedonian, Slovenian and Serbian newspapers is in constant decline in these three decades. Editors with their media agenda are mostly focused on the process of collecting, processing and creation of content on those local topics relevant for the countries where these media operate. Their major shift to national and local level is a big surprise in these specific moments of the second era of globalization, characterized by mobility of capital and working staff around the world, free flow of information, mobility programs for students, new media and communication technologies. Empirical results show greater openness to international topics in the Macedonian, Slovenian and Serbian newspapers during the research periods of 1983 and 1989. But, we should not omit the fact 
that the former Yugoslavia in the past had a proactive role on the international political scene through its leading position among non-aligned countries.

Two more factors may mitigate the negative conclusion for international reporting of the newspapers Nova Makedonija, Vecer, Delo and Politika. As first, actual structure of daily newspapers is much more developed in comparison with the issues printed in 1983 and 1989. The total number of sections is increasing from year to year, giving the same media space to different social segments. Thus, there is a big possibility that media content, which was in the past placed in foreign policy sections, today is going to be published in one of the newly formed sections. On the other hand, we should not forget the fact that media today are publishing more extensive articles in their printed editions. Consequently, the limited space in their printed issues leads to reduction in the total number of published texts.

Gate-keeping theory inevitably plays key role in foundation of the international reporting. The selection of topics is a powerful tool in the hands of journalists, process that is relevant to the present day. Editors and journalists of today's newspapers are playing the same role as those media personnel that were responsible for international reporting in 1983 and 1989. The selection of news in media will continue to operate as one of the key functions of journalists. There are two obvious differences in the gatekeeping, if we compare the current situation to the period of three decades ago. The first difference is the fact that the number of media is growing fast today, and thus, there are more professionals that play the role of gatekeepers. Beyond traditional media, in the selection of news are included citizens - journalists with their content published on social networks. This means greater pluralism in the media presentation of world events.

Despite all interpretations of the similarities and differences in international reporting, remains the fact that there is presence of continuous reduction in the number of media content for foreign policy events. The decline of the quantum of texts in the 2013 printed editions of the Macedonian, Slovenian and Serbian newspapers can bring further reduction in the quality of these media. This kind of news selection can result only with deeper lack of knowledge between the public on actual international affairs. 


\section{References}

Bennett, W.L. (2012). News: The Politics of Illusion. 9th edn. New York: Longman.

Bird, S. E. (ed.) (2010). The Anthropology of News \& Journalism: global perspectives. Bloomington, Indianapolis: Indiana University Press.

Davies, N. (2009). Flat Earth News: An Award-Winning Reporter Exposes Falsehood, Distortion and Propaganda in the Global Media. London: Vintage Books.

Fenko, B.A. and Sabic. Z. (2013). "Continuity and Change in Slovenia's Foreign Policy: A Comparison to Yugoslavia and an Analysis of the Post-independence Period". Available from http://www.eisa-net.org/bebruga/eisa/files/events/warsaw2013/Bojinovic\%20Fenko\&Sabic_Continuity\%20and \%20Change\%20in\%20Slovenia's\%20Foreign\%20Policy.pdf (Accessed 12.10.2017).

Gavranov, V. \& Stojkovic, M. (1972). Međunarodni odnosi i spoljna politika Jugoslavije [International Relations and Foreign Policy of Yugoslavia]. Belgrade: Savremena administracija. [In Serbian]

Gerbner, G. \& Marvanyi, G. (1975). The Many Worlds of The World's Press: A multinational cooperative and comparative study of foreign news coverage. The Annenberg School for Communication at University of Pennsylvania. Available from http://web.asc.upenn.edu/gerbner/Asset.aspx?assetID=1648 (Accessed 10.06.2015).

Hatchen, A.W. \& Scotton, F.J. (2012). The World News Prism: Challenges of Digital Communication. 8th edn. Chichester: Wiley-Blackwell.

Herman, S. E. \& Chomsky, N. (1988). Manufacturing Consent: The Political Economy of the Mass Media. New York: Pantheon Books.

Kardelj, E. (1985). The Historical Roots of Non-Alignment. Washington: University Press of America.

Kunczik, M. \& Zipfel, A. (1998). Introduction to the Science of Publicism and Communication. Skopje: Foundation Friedrich Ebert. [In Macedonian]

McChesney, W. R. (2008). The Political Economy of Media. New York: Monthly Review Press.

McNair, B. (2011). An Introduction to Political Communication. 5th edn. Abingdon: Routledge.

Meyer, T. (2003). Media Democracy: How the Media Colonize Politics. Zagreb: Faculty of Political Science, University of Zagreb. [In Croatian] 
Nacev, Z. \& Petreski, T. (2013). Стратегиски проекции на Република Македонија во надворешната и безбедносната политика [Strategic Projections of the Republic of Macedonia in Foreign and Security Policy]. Kocani: Evropa 92. [In Macedonian]

Novakovic, I. (2012). Neutralnost u Evropi u 21 veku i slučaj Srbije [Neutrality in Europe in the XXI century and the Case of Serbia]. Available from https://www.isacfund.org/download/Neutralnost_u_Evropi_u_21_veku_i_slucaj_Srbije.pdf (Accessed 12.10.2017). [In Serbian]

Radeljic, B. (2012). Europe and the Collapse of Yugoslavia: The Role of Non-State Actors and European Diplomacy. New York: I.B. Tauris \& Co Ltd.

Shafer, R. (1997). "The Press and the Preservation of Yugoslavija Before 1990: TANJUG's Leadership of the Non-Aligned News Agencies Pool". The Global Network, 8, 56-69.

Street, J. (2003). Mass Media, Politics and Democracy. Zagreb: Faculty of Political Science, University of Zagreb. [In Croatian]

Topuz, H. (1977). The News Agencies Pool of Non-Aligned Countries. UNESCO. Available from http://unesdoc.unesco.org/images/0002/000247/024782eb.pdf (Accessed 12.10.2017).

Zixue, T. (2005). "News Events, News Values and Editors' Judgments: The Cases of China, Taiwan and Japan". Global Media Journal, American Edition, 6 (2). http://www.globalmediajournal.com/open-access/news-events-news-values-andeditors-judgments-the-cases-of-china-taiwan-and-japan.pdf (Accessed 12.10.2017). 